\title{
Beralih ke Haluan Islamisme: Gen Z, Media Sosial \& Intoleransi di Indonesia
}

\author{
R. Cecep Romli \\ UIN Syarif Hidayatullah Jakarta \\ cecep.romli@uinjkt.ac.id
}

\begin{abstract}
Abstraks: Saat ini, ekspresi politik identitas dan islamisme tampak menguat di banyak kanal media sosial. Tulisan ini bertujuan mencermati sejauhmana mainstream moderatisme NU dan Muhammadiyah digerogoti oleh intoleransi Islamisme. Berpijak pada data berbagai survei-dan merujuk pada definisi islamisme dari Mozaffari -, ditemukan bahwa tak sedikit pengajar serta siswa dan mahasiswa (generasi Z) yang merasa dekat dengan NU dan Muhammadiyah, namun bersimpati atau bahkan "menyeberang" ke haluan islamisme.
\end{abstract}

Kata Kunci: Gen Z, Islamisme, Moderatisme, Kampanye, Media Sosial, Industri Kebencian

Permalink/DOI: http://doi.org/10.15408/dakwah.v22i1.12045

\section{Pendahuluan}

Saat ini, warganet melonjak mencapai jumlah fantastis. Netizen Indonesia saja mencapai 143,3 juta jiwa atau separuh lebih dari 262 juta penduduk, bersamaan dengan 4 miliar warganet dunia yang juga separuh lebih 7 miliar penduduk dunia. Bandingkan dengan jumlah netizen Indonesia pada 2009 yang baru 30 juta jiwa (Survei APJII, 2018).

Namun, lonjakan tersebut sekaligus mengubah total wajah internet. Pada 8 tahun terakhir ini internet telah didominasi oleh medsos dan meme yang sering bersifat parsial dan partisan, tidak lagi oleh situs dan blog (Iman, 2016). Global Digital Report 2018 melaporkan, lebih dari 3 miliar netizen menggunakan medsos setiap bulan, dan 90\% dari mereka mengaksesnya dengan handphone (wearesocial.com). Riset PPIM UIN Jakarta 2017 pun mengungkapkan, mayoritas siswa dan mahasiswa (50, 89\%) memfavoritkan medsos sebagai sumber pengetahuan agama, dan hanya 3,98\% saja yang suka membaca situs atau blog (Lihat tabel 1 dan 2).

Dampaknya mengerikan. Eksploitasi medsos malah menjadi pemantik tren intoleransi dan kebencian global. Di Timur Tengah, bara berlarut khususnya di Yaman, Irak, dan hingga kini ISIS di Suriah tak lepas dari ledakan amarah berbau SARA dan propaganda medsos. Pun Amerika dan Eropa kini dikuasai sentimen anti Muslim dan anti imigran dengan menangnya Donald Trump dan Referendum Brexit. Asia diterpa sentimen anti Muslim di Myanmar dan India. Di Indonesia sendiri tengah bergejolak kebencian dan perseteruan antara kubu Aksi Bela Islam 212 dan kubu anti 212. 

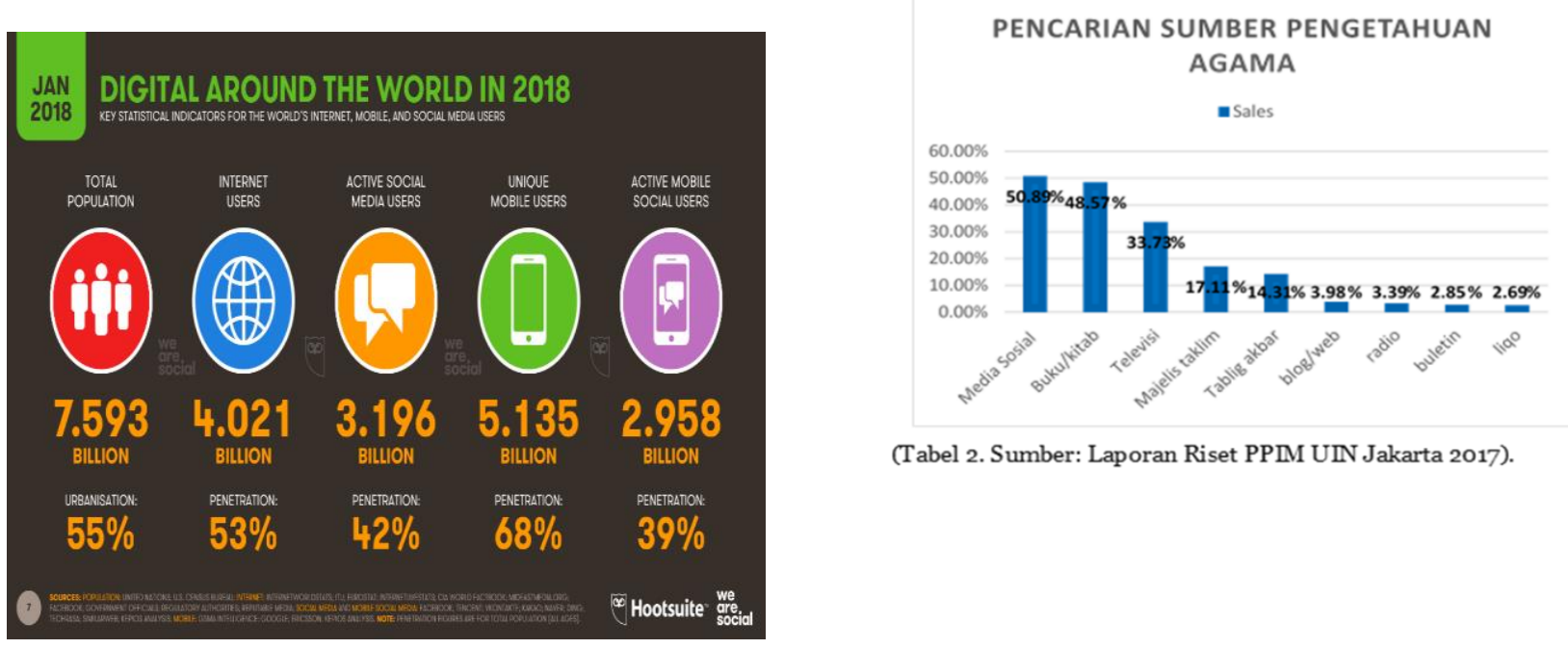

(Tabel 2. Sumber: Laporan Riset PPIM UIN Jakarta 2017).

Tabel 1. Sumber: wearesocial.com)

Dampaknya, tak sedikit netizen rentan terjalar kebencian dan permusuhan. Mayoritas netizen Indonesia atau sebanyak 49,52\% (sekitar 71,5 juta jiwa) adalah usia 19-34 (kompas.com dari survei AJPII), "anak zaman now" yang dikenal rendah minat baca. Maka intoleransi dan ujaran kebenciang memang tengah mengancam jutaan mereka. Kasus banyaknya remaja WNI sekitar 541 orang yang bergabung ke ISIS, juga sekitar 931 warga Jerman dan warga Eropa lainnya, merebaknya hoax dan ujaran kebencian pra terbongkarnya sindikat Saracen dan MCA pada awal 2017, seringnya kasus persekusi atas nama agama, semua menjadi lonceng peringatan yang tak bisa diabaikan.

Apakah fenomena ini secara signifikan telah menggerogoti mainstream Islam moderat NU dan Muhammadiyah, terlebih di kalangan muda dua ormas Islam ini? Adakah harapan untuk mengembalikan pendulum sosial ke arah pengarusutamaan religiusitas yang moderat dan toleran?

Sejumlah Indonesianis seperti William Liddle, Greg Fealy, dan Krithika Varagur telah mengemukakan pandangan tentang topik ini. Hanya saja pandangan mereka tidak ditopang banyak data. Menggunakan data-data empirik dari sejumlah survei, tulisan ini akan fokus pada seputar pertanyaan ini.

\section{Pembahasan}

\section{Pertarungan Kuasa \& Industri}

Tak bisa dipungkiri, gambaran medsos tidak sepenuhnya buram. Di sisi lain, medsos pula yang melahirkan revolusi profesi baru dan kreasi perusahaan digital, yang umumnya digerakkan oleh anak zaman now. Ruang medsos telah melahirkan e-entrepreneur gemilang semacam selebgram (Ria Ricis, Devina Aureel, Kadir Bachmid, Nurul Azka @nunuzoo, mahasiswi Fidikom UIN Jakarta dsb),youtuber (ChandraLiow, Atta Halilintar, Edho Zell, Wirda Mansur dsb), blogger (Noni Khairani, Aldy Terenz, Emak Gaoel dsb); juga pesatnya perusahaan digital seperti kaskus, olx, traveloka, bukalapak dan sebagainya. Tak kalah pentingnya lahir pula bintang-bintang kiai dan ustad zaman now yang membawa kesejukan: punya bobot ilmu, asyik, dan moderat. Namun, eksploitasi medsos oleh jempol-jempol kebencian tampaknya tengah memegang dominasi. 
Banyak asumsi, pertarungan antara kubu 212 dan "Ahoker" merupakan pertarungan antara kubu anti demorasi dan pro demokrasi, antara kubu sektarianisme (eksklusif) dan Islam moderat (inklusif), atau antara kubu pemilih yang rasis dan pemilih yang rasional. Namun, asumsi ini, menurut Marlyna Lim (2018), tidak sepenuhnya sesuai kenyataan. Membingkai kontestasi itu dengan oposisi biner semacam itu (bisa) menyesatkan (misleading). Sebab, pada prakteknya, kampanye online dan medsos kedua kubu sama-sama diwarnai kampanye "hitam", misalnya dengan mem-framing berita dan cerita yang menyebelah (one-sided information).

\begin{tabular}{|c|c|}
\hline Situs Pro Ahok & Situs Anti Ahok \\
\hline http://www.seword.com & http://www.posmetro.info \\
\hline http://www.gerilyapolitik.com & http://www.saracennews.com \\
\hline http://www.beraninews.com & https://pembawaberita.com \\
\hline http://www.itukoran.com & http://www.muslimbersatu.net \\
\hline http://www.cerianews.com & http://www.mediaopini.com \\
\hline http://www.benderanews.club & http://berita.islamedia.id \\
\hline http://www.permatanews.com & http://www.opinibangsa.id \\
\hline http://www.funesia.net & http://wwwidnusa.com \\
\hline http://www.beritakepo.com & http://www.mimbarmerah.net \\
\hline https://www.berita168.com & http://www.portal-islam.id \\
\hline http://www.infoteratas.com & http://www.portal-piyungan.com \\
\hline http://www.pkspuyengan.com & http://portalpiyungann.blogspot.com \\
\hline http://arrahmahnews.com & http://www.arrahmah.co.id \\
\hline http://voa-islamnews.com & http://www.voa-islam.com \\
\hline https://aksiberita.blogspot.ca & http://www.mediabangsaku.com \\
\hline$\frac{\text { https://beritatribunnews.wordpress.com }}{\text { (Sumhar: Marluna I im sort }}$ & http://informasivoa.blogspot.ca \\
\hline
\end{tabular}

Lim melacak puluhan situs masing-masing kubu (tabel 2). Hasilnya, peneliti jurnalistik dari Carleton University Canada ini menemukan bahwa tidak benar kalau hanya kubu anti Ahok yang melakukan kebohongan. Kedua kubu sama-sama melakukan politik post-truth, dengan memframing berita dan cerita yang menggugah emosi, yang hanya sedikit atau tidak sama sekali berhubungan dengan detail kebijakan dan fakta. "Post-truth" adalah kata sifat yang berarti suatu keadaan di mana daya tarik emosional lebih berpengaruh dalam membentuk opini publik daripada fakta yang objektif (Iman, 2016).

Lebih jauh Lim membuktikan, sejumlah situs pro Ahok pun menyebar konten rekaan dan superfisial. Misalnya sebagian situs pro Ahok itu sebenarnya hanya tiruan (spoof) dari sejumlah situs milik grup islamist. Ada arrahmahnews.com (tiruan dari arrahmah.com), voa-islamnews.com (tiruan dari voa-islam.com), dan pkspuyengan.com (tiruan dari portal-piyungan.com). Selama masa kampanye Pilkada Jakarta, situs-situs grup islamist itu gencar menebar pandanganpandangan konservatif dan sektarian yang bersifat anti Ahok, sedangkan situs-situs tiruan itu menyebar konten-konten yang pro Ahok, anti Anies dan anti islamist. Situs-situs tiruan itu dikelola untuk menarik banyak pengunjung (hit). Misalnya dari 18 Maret-18 April 2017, arrahmahnews.com telah memikat 88.00o pengunjung, bandingkan dengan 259.0oo pengunjung arrahmah.com. Banyak kampanye anti Ahok mencela suku dan agama Ahok, melabelinya sebagai kafir dan komunis. Sebagai balasan, kubu pro-Ahok pun mengarang fakta-fakta yang meliputi banyak isu, terutama menuduh Anies terlibat banyak kasus korupsi, berencana memerintah Jakarta di bawah hukum syariat, dan bahwa ia didukung Syiah Iran, ISIS dan Al-Qaeda. 
Lim juga menggarisbawahi bahwa kedua kubu sama-sama menggunakan jasa perusahaan cyber, yang melibatkan ribuan buzzer dan banyak opinion leader berbayar. Jadi, simpulnya, alihalih tepat dibaca dengan oposisi biner, kontestasi itu sebenarnya lebih merupakan praktek politik post-truth.

Riset Lim ini sekaligus membuktikan bahwa aktor utama di balik kisruh SARA sebetulnya lebih kepentingan politisi partisan daripada paham keagamaan. Hal ini sejalan belaka dengan pandangan Cherian George dalam bukunya Hate Spin; The Manufacture of Religious Offense and Its Threat to Democracy. Berdasar tinjauan empiriknya di tiga negara sekaligus, Amerika, India, dan Indonesia, ia berpandangan bahwa politik kebencian itu terkait agenda kampanye masif para entrepreneur politik untuk memobilisasi dukungan dan menjatuhkan lawan (Cherian George, 2016).

Hal ini pula yang dikuatkan oleh temuan Savic Ali, tokoh muda PBNU dan direktur NU Online dan islam.co. Selama 3 bulan (Oktober-Desember 2017), ia bersama timnya melakukan tracking terhadap ribuan kata kunci dan postingan (status) di ribuan akun facebok dan twitter. Temuannya ternyata 80 persen ujaran kebencian bukan berasal dari akun-akun yang teridentifikasi orang (berpaham keagamaan) fundamentalis, melainkan datang dari akun-akun partisan politik (beritasatu.com, 2018).

Temuan Savic sekaligus membuktikan kian mengguritanya barisan buzzer di media sosial. Di balik permukaan yang memesona, para entrepreneur politik, puluhan perusahaan cyber dan ribuan buzzer itu berjejaring dan bersekongkol di bawah satu komando yang sama: uang dan kuasa. Tidak tertutup kemungkinan, satu perusahaan cyber "bermain di dua kaki”, melayani dua clien politikus yang sedang beradu. Meski hal ini tidak masalah sejauh tidak melibatkan politik kebencian SARA dan konten rekaan. Komoditas SARA dan konten rekaan itulah yang merusak sendi-sendi Islam dan demokrasi di Indonesia.

Peninjauan Lim benar adanya dan objektif. Dua kubu sama-sama tidak lepas dari praktek politik post thruth. Hanya saja, Lim tidak menukik lebih jauh di kubu mana komoditas SARA, hoax dan ujaran kebencian itu banyak dipompakan. Namun, fokus tulisan ini bukanlah politik partisan (kubu-kubuan), melainkan tentang sikap moderatisme keagamaan NU dan Muhamadiyah yang selama ini dipandang mainstream.

\section{NU dan Muhammadiyah Digerogoti}

Sejauh ini, belum ada data yang meyakinkan tentang sejauhmana moderatisme NU dan Muhammadiyah tergerogoti oleh propaganda Islamisme. Atau, sejauhmana propaganda Islamisme mampu menembus jantung moderatisme massa dan kelas menengah NU dan Muhammadiyah. Namun, banyak indikator pengamatan yang mengafirmasi kenyataan ini.

Aksi damai Bela Islam 212 dimotori oleh GNPF-MUI, grup berhaluan "islamist” yang terdiri dari FPI, HTI, FUI, dan MIUMI. Walau begitu, survei yang dilakukan Hadiz dan Rakhmani menemukan bahwa hampir 60\% peserta aksi Bela Islam 212 (dengan sampel 600 orang) mengakui afiliasi kepada NU dan Muhamadiyah, dua organisasi Islam yang dikenal sebagai garda depan Islam moderat. Mayoritas peserta juga anak muda, yaitu 60\% responden usia 20 tahun, $18 \%$ usia 30 tahun, dan hanya 14\% yang di atas 40 tahun (Hadiz \& Rakhmani, 2017). 
Namun, hal ini tidak berarti bahwa seluruh peserta NU dan Muhammadiyah pada aksi Bela Islam 212 itu serta merta berputar haluan berpihak dan menganut ideologi dan agenda politik FPI. Kesamaan aspirasi terhadap satu isu (tuntutan pemenjaraan Ahok yang dipandang telah menista Islam) tidak lantas menunjukkan kesamaan paham (agama) dan ideologi. Itu sebabnya dalam pengamatan (observasi) Greg Fealy, hanya sedikit dari peserta 212 itu yang tampak terafiliasi dengan dan tertarik pada agenda FPI. Bagi mayoritas peserta, aksi damai ini lebih merupakan sebuah momen religius, baik dalam arti untuk membela Islam dari penistaan (oleh Ahok) maupun untuk ekspresi kesalehan dengan ikut shalat dalam massa raksasa di monumen nasional (Fealy, 2017).

Bagi Fealy, sangat jelas ekspresi banyak peserta aksi itu tampak lebih tertarik pada aspekaspek religius dari aksi daripada mengecam si China Ahok. Seorang peserta wanita dari NU pun berkata, "Saya di sini untuk membela Islam dan Al-Quran dari penistaan. Tapi saya menolak bila ini untuk mendukung FPI dan HTI.” Karena itu salah satu poin penting dari amatan Fealy adalah, mereka datang untuk membela Islam, bukan membela islamisme (FPI).

Namun, bagi Varagur, bergabungnya warga NU pada aksi 212 tetap saja dipandang sebagai pertanda mulai merapuhnya Islam moderat. Di antara dasar penilaiannya ini adalah pengamatan Pengamat Politik William Liddle dan pengamatan Alissa Wahid, putri Abdurrahman Wahid. Liddle mengatakan, banyak ulama NU telah menjadi konservatif. "Selama dan sejak Presiden Wahid, kesan bahwa paham moderat itu mendominasi NU tak pernah lagi akurat." Alissa mengatakan, "Dalam 15 tahun terakhir, warga NU menjadi konservatif tidak saja dalam ritual tapi juga kasar, memaksakan suatu perspektif mayoritas yang membubarkan seluruh paham Islam lainnya, mengistimewakan sendiri di tengah banyak agama lain.”

Merujuk pada definisi islamisme dari Mehdi Mozaffari, tulisan ini berpandangan bahwa moderatisme di tubuh NU dan Muhammadiyah memang tengah tergerogoti oleh (propaganda) islamisme. Islamisme dalam rumusan Mozaffari adalah suatu ideologi religius dengan satu interpretasi holistik tentang Islam, yang tujuan finalnya adalah menaklukkan dunia dengan segala cara (a religious ideology with a holistic interpretation of Islam whose final aim is the conquest of the world by all means) (Mozaffari, 2007). Namun, dalam tulisan ini, batasan dari Mozaffari tidak sepenuhnya dijadikan "definisi operasional".

Salah satu yang banyak menggerototi moderatisme NU dan Muhammadiyah itu adalah islamisme FPI. FPI memang bukan ormas (organisasi masyarakat) Islam yang menghalalkan segala cara, dan sejauh ini tidak terbukti hendak menaklukkan dunia. Namun, mengikuti rumusan Mozaffari, Islamisme FPI tampak pada dua aspek. Pertama, paham "interpretasi holistik" FPI yang absolut tentang Islam, sehingga FPI memonopoli interpretasi ayat tertentu dan menafikan banyak interpretasi ulama lain. Akibatnya FPI hendak meletakkan Al-Quran di atas konstitusi. Memonopoli interpretasi dan hendak meletakkan Al-Quran di atas konstitusi jelas merupakan Islamisme.

Islamisme bertentangan dengan Islam (moderat) NU dan Muhammadiyah, karena mainstream dua organisasi ini berpandangan bahwa Pancasila dan UUD 45 yang melindungi dan memayungi seluruh kitab suci termasuk Al-Quran itu justru telah cocok dengan praktek histroris Piagam Madinah Nabi saw, yang sama sekali tidak memformalisasi Al-Quran menjadi konstitusi negara. Piagam Madinah merupakan pijakan historis yang otentik, yang diyakini oleh mainstream 
tokoh-tokoh NU dan Muhammadiyah, seperti Gus Dur, Gus Mus, Agil Siradj, Buya Syafii Maarif, Kuntowijoyo, Haidar Nasir, juga oleh mainstream cendikiawan dan akademisi semisal M.Quraish Shihab, Nurcholish Madjid, Dawam Rahardjo, Azyumardi Azra, Komarudin Hidayat, Dede Rosyada, dan sebagainya.

Aspek kedua dari islamisme FPI adalah dukungannya pada sistem khilafah dan aksi kekerasannya dalam sweeping dan razia, selain aksi serangannya terhadap aksi aliansi (kelompok) lain. FPI mengatakan tidak mendukung ISIS, tapi juga tidak memusuhi dan tidak menolak ISIS karena bisa saja pada situasi nanti ISIS diperlukan. FPI juga tidak anti terhadap kebiadaban pembantaian oleh ISIS terhadap aparat polisi dan tentara Irak, karena dipandangnya sebagai perlawanan atas kelaliman polisi dan tentara (HRS, 2014 pada milad FPI ke 16).

Tak bisa dipungkiri, FPI memperoleh panggung yang besar untuk menebarkan islamismenya dalam Aksi Damai Bela Islam 212 (2 Desember 2016). Pengaruh besar itu diperolehnya karena mendapat sokongan otoritas dari fatwa MUI. Atas dasar legitimasi fatwa itu dibentuklah GNPFMUI, grup berhaluan "islamist” (terdiri dari FPI, HTI, FUI, dan MIUMI) yang memotori aksi 212.

Seiring dengan itu, ditemukan 3 indikator dari data empirik tentang melonjaknya dukungan terhadap Islamisme yang menggembosi moderatisme NU dan Muhammadiyah.

Pertama, lonjakan dukungan terhadap larangan non Muslim menjadi gubernur dari kalangan NU dan Muhammadiyah. Salah satu alasan yang mendongkrak dukungan ini adalah alasan yang dikhutbahkan HRS pada khutbah Jumat Aksi Bela Islam 212 (2 Desember 2016) di Monas, yaitu bahwa larangan ini adalah mutlak dari Al-Quran, sedangkan Al-Quran harus berada di atas konstitusi. Sekitar 8 bulan sebelum Aksi Bela Islam 212 apalagi menjelang Pilkada DKI Jakarta 19 April 2017, cukup banyak ulama dan ustad NU dan Muhammadiyah yang menyuarakan larangan yang dianggap mutlak dari Al-Quran ini. Padahal, sejak 1999 PBNU telah mengeluarkan fatwa mengenai bolehnya non Muslim menjadi pemimpin. Artinya, proses pergeseran keberpihakan kalangan NU terhadap paham dan ideologi Islamist FPI memang benar-benar terjadi menjelang, pada saat dan setelah aksi 212.

Pada survei PPIM 2017, terungkap bahwa mayoritas guru PAI dan dosen PAI Indonesia (64,29\%) merasa paling dekat dengan Nahdhatul Ulama (NU), dan sebanyak 30,75\% siswa dan mahasiswa merasa paling dekat dengan Muhammadiyah (lihat tabel 3 dan 4). Dua ormas Islam yang dikenal moderat ini begitu pavorit di kalangan Guru PAI dan dosen PAI, dua kelompok elit agama yang punya peran besar dalam membentuk opini dan paham keagamaan. Namun, mayoritas mereka (67,08\%) tidak setuju (atau keberatan) jika non Muslim menjadi gubernur (lihat tabel 5) . Artinya, banyak guru PAI dan dosen PAI yang secara keagamaan paling dekat dengan NU ternyata sudah "menyeberang" ke paham islamist FPI. 


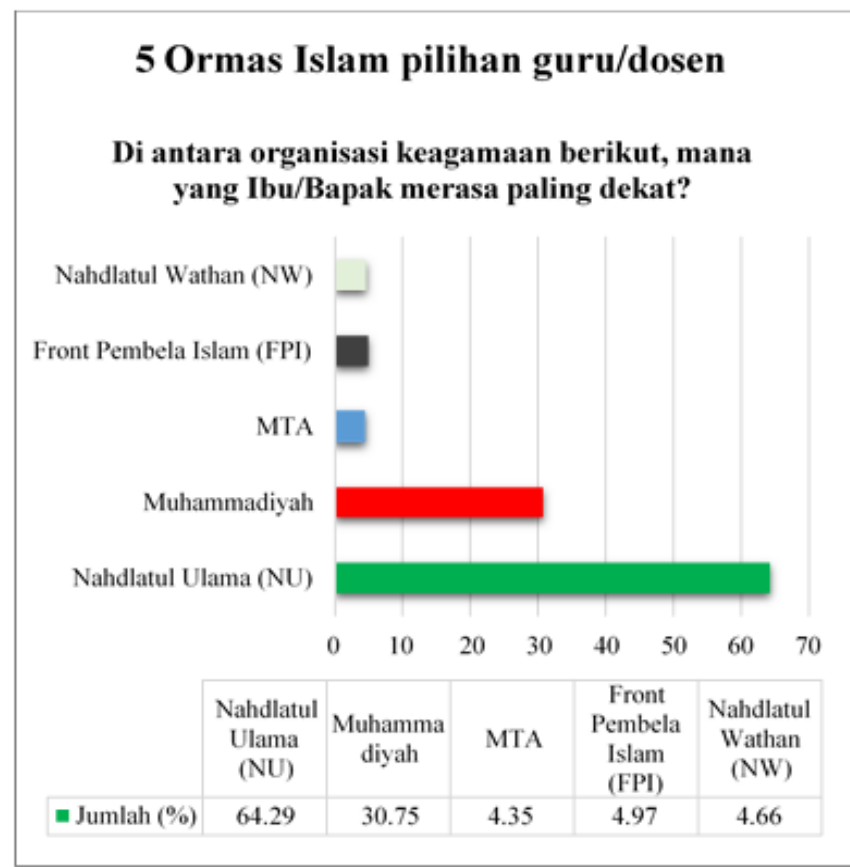

(Tabel 3. Sumber: Laporan Riset PPIM UIN Jakarta 2017)

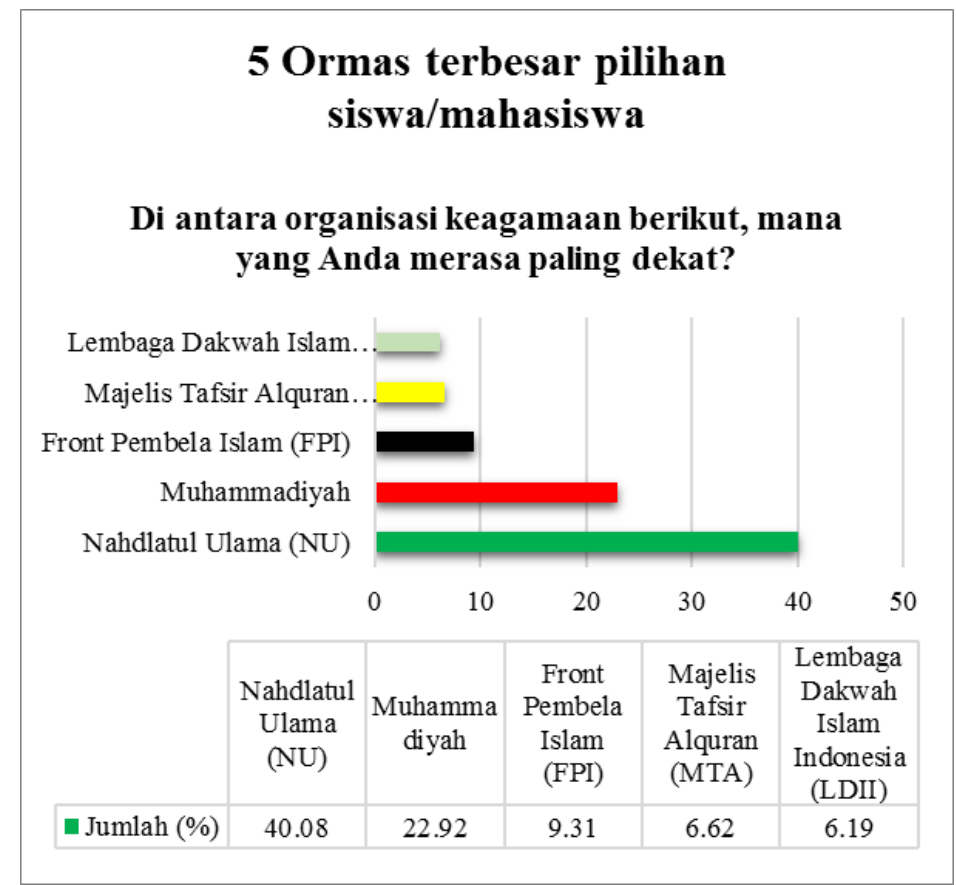

(tabel 4. Sumber: Laporan Riset PPIM UIN Jakarta 2017)

Data serupa ditunjukkan oleh data-data "multi years" LSI (Lembaga Survei Indonesia dan SMRC (Saiful Mujani Research). Survei LSI menunjukkan lonjakkan dukungan sebesar 7,9 \% pada 2017 dibanding 2016 terhadap larangan non Muslim menjadi gubernur; pada 2017 dukungan sebanyak 48,2\% sedangkan pada 2016 sebanyak 40,3\%. Sedangkan survei SMRC khusus untuk pemilih Jakarta, menunjukkan lonjakan drastis dari 47\% dukungan menjadi $62 \%$ dukungan (Mietzner dan Muhtadi, 2018). 


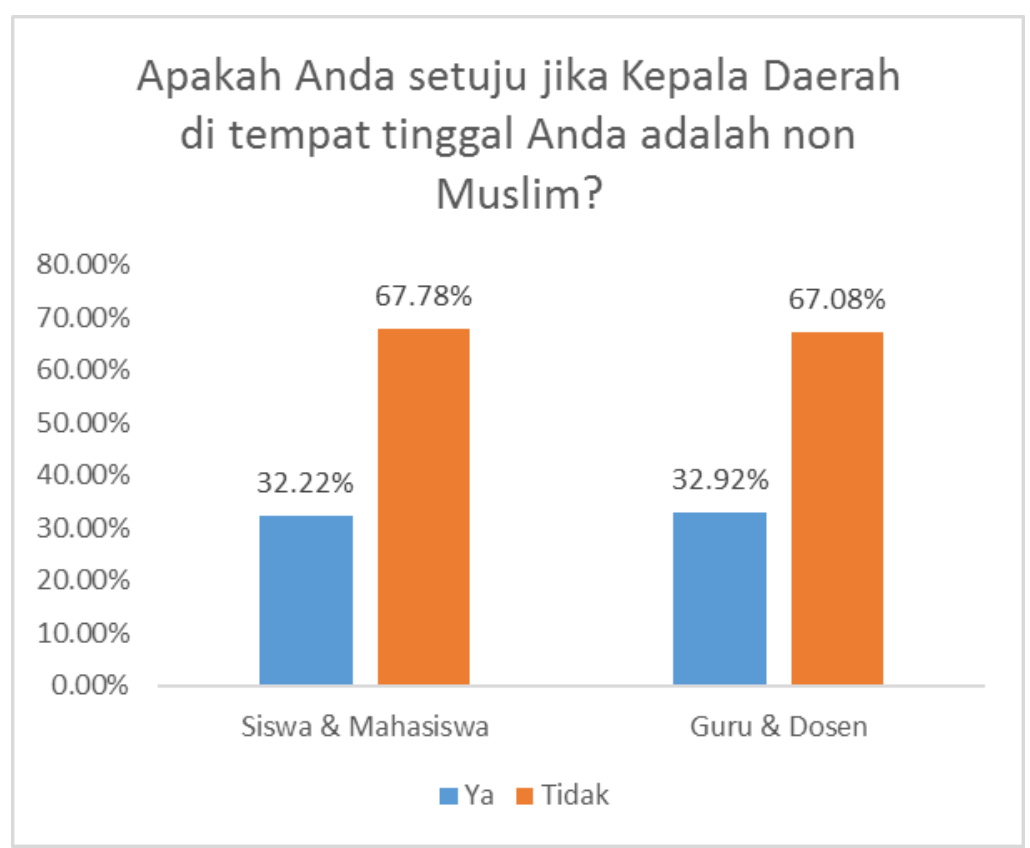

(tabel 5. Sumber: Laporan Riset PPIM UIN Jakarta 2017)

Perlu dicatat, berpendapat atau mengikuti pendapat bahwa pemimpin non Muslim itu dilarang dalam Islam tidaklah otomatis membuat seseorang menjadi islamist atau berpaham islamisme, sejauh ia tetap toleran dan menghargai pendapat ulama lain dalam Islam. Sebab, dalam definisi Mozaffari, yang menjadi ciri islamisme itu adalah interpretasi holistik (holistic interpretation), yang bersifat total dan tunggal sehingga menafikan perbedaan pendapat dan mengikis moderatisme Islam.

Berpendapat atau mengikuti pendapat tentang kebolehan pemimpin non Muslim juga tidak otomatis menjadi dukungan pada cagub tertentu. Sebab, kebolehan secara notmatif bukan keharusan (kewajiban), terlebih karena cagub bersangkutan pun belum tentu termasuk kriteria cagub non Muslim yang diperbolehkan. Pendapat ini tidak terkait langsung dengan politik partisan.

Kembali ke indikator terkikisnya mainstream moderatisme Islam. Indikator kedua, kedekatan remaja dengan NU dan Muhammadiy-ah jauh lebih kecil dibanding kedekatan orang tua dengan dua ormas ini. Pada survei yang sama oleh PPIM UIN Jakarta 2017, ditemukan sebesar 40,08\% siswa dan mahasiswa merasa dekat dengan NU, dan 22,92\% siswa dan mahasiswa merasa dekat dengan Muhammadiyah. Bandingkan dengan kedekatan guru dan dosen dengan dua ormas ini, yaitu sebesar 64,29\% guru dan dosen merasa dekat dengan NU, dan sebesar 30,75\% merasa dekat dengan Muhammadiyah. Rendahnya kedekatan remaja dengan NU 


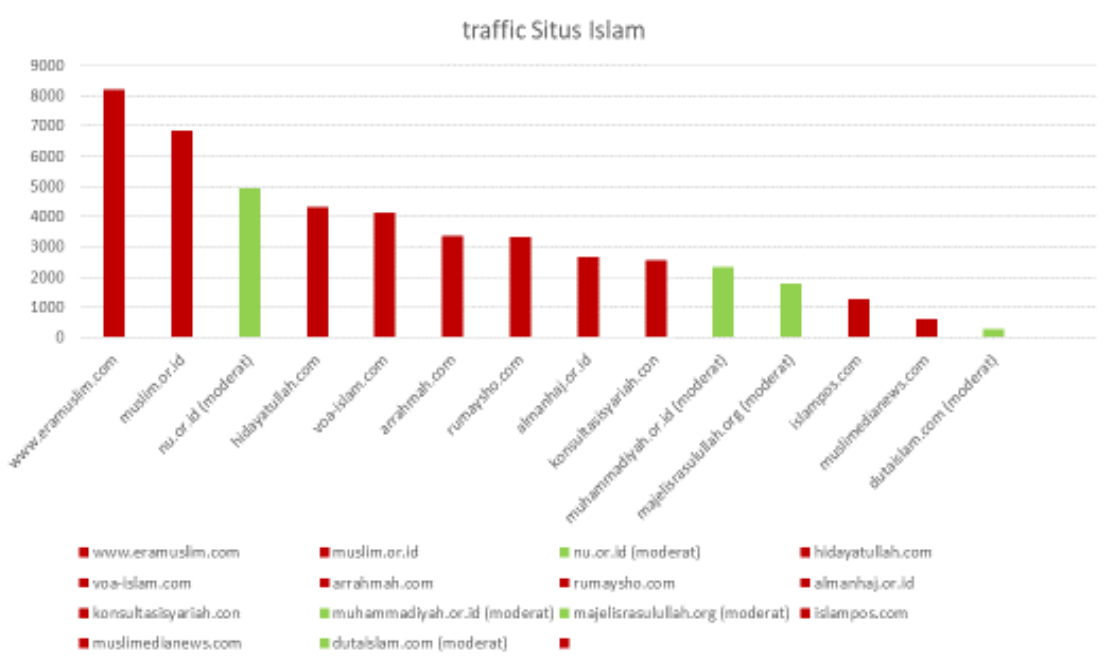

(Tabel 7: perbandingan traffic situs-situs Islam intoleran [merah] dan situs-situs Islam moderat [hijau]. Sumber: dioleh dari Alexa dan data traffic dari tools.neilpatel.com, 15 dan 16 September 2018).

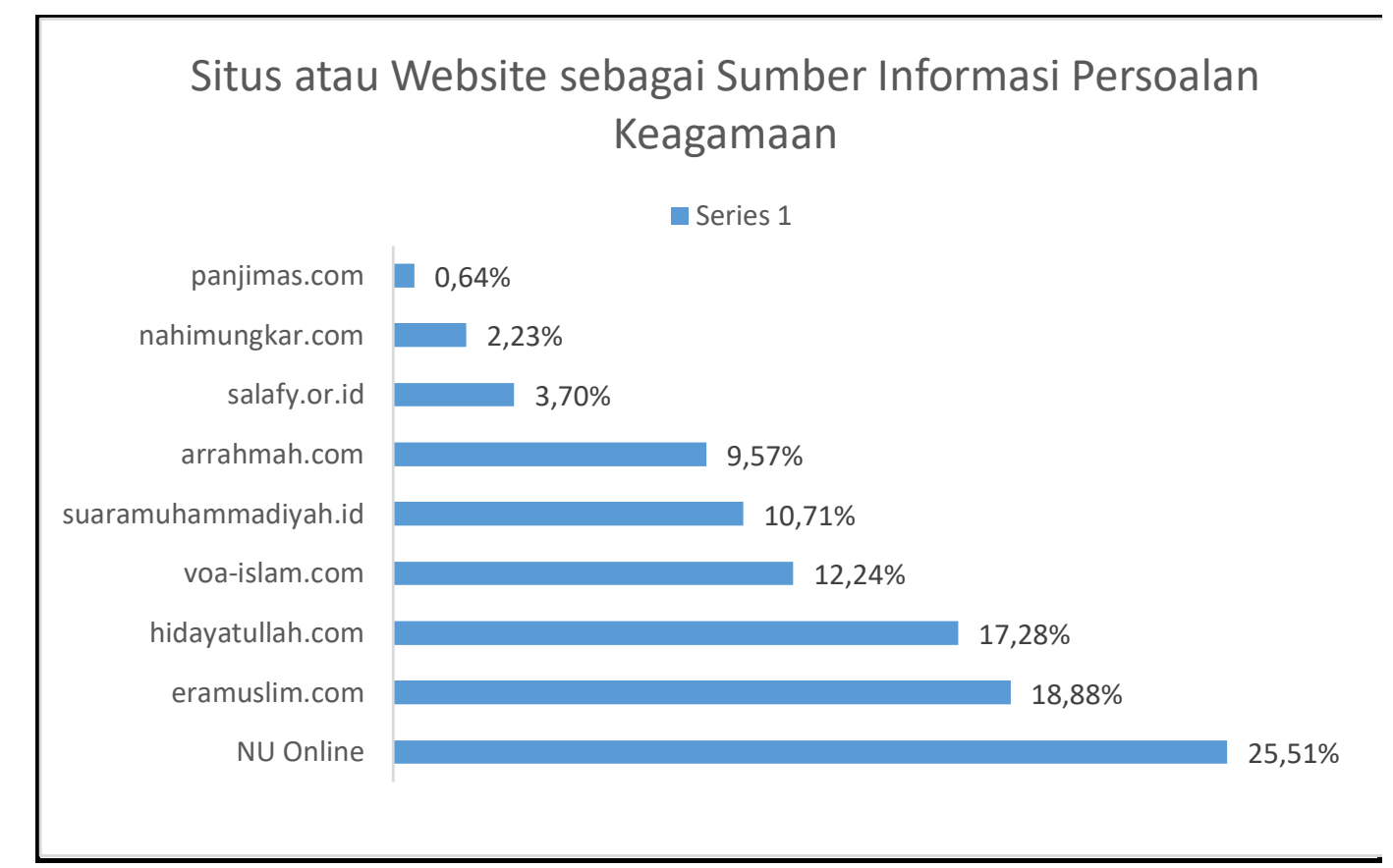

(tabel 8. Sumber: Survei PPIM UIN Jakarta 2017)

dan Muhammadiyah jika dibanding dengan kedekatan orang tua-dapat menjadi penjelasan tentang dominasi remaja dan pemuda pada peserta aksi Bela Islam 212, sebagaimana telah disebutkan, yaitu 60\% peserta usia 20 tahun, $18 \%$ usia 30 tahun, dan hanya $14 \%$ yang di atas 40 tahun (Hadiz \& Rakhmani, 2017). Hal itu pula yang menjelaskan kenapa kedekatan siswa dan mahasiswa kepada FPI jauh lebih tinggi (9,31\%) dibanding kedekatan guru dan dosen kepada grup islamist ini (4,97\%) (lihat tabel 5 \& 6). 
Ketiga, melonjaknya popularitas situs-situs Islam berhaluan keras (intoleran). Pada saat yang sama, jumlah pengunjung (traffic) pada situs NU dan Muhammadiyah (dan situs islam moderat lainnya) jauh lebih kecil dibanding jumlah prosentase remaja yang dekat dengan NU dan Muhammadiyah (lihat tabel 7 dan 8).

Jumlah remaja yang merasa dekat dengan NU sebesar 40,08\%, dan siswa dan mahasiswa merasa dekat dengan Muhammadiyah 22,92\% (lihat tabel 5); atau seluruhnya berjumlah 63\%. Namun, jumlah pengunjung NU Online dan suaramuhammadiyah.id dari kelompok netizen siswa dan mahasiswa yang mencari informasi keagamaan seluruhnya hanya berjumlah 36, 22\% (pengunjung NU online 25,51\% dan pengunjung suaramuhammadiyah 10,71\%). Artinya, banyak siswa dan mahasiswa yang dekat dengan NU dan Muhammadiyah tidak berkunjung ke situs dua ormas Islam ini ketika mencari informasi keagamaan.

\section{Media Sosial Alat Pemonopoli Tafsir}

Pada Pilkada Surakarta 2010, PKS mendukung pasangan Jokowi dan Hadi Rudyatmo, seorang non Muslim. Saat itu Dewan Syariah PKS Surakarta mengeluarkan fatwa yang membolehkan non Muslim menjadi pemimpin. Dasar fatwa ini adalah kajian fiqih dan tafsir yang komprehensif dan berimbang, dengan rujukan ulama klasik dan kontemprorer yang otoritatif dan meyakinkan. Salah satu ayat yang dikaji utuh oleh fatwa ini adalah Al-Maidah: 51, yang dijelaskan secara terang bahwa ayat ini (dan ayat terkait lainnya) menjadi titik tolak yang sama baik bagi ulama yang melarang maupun yang membolehkan pemimpin non Muslim.

Saat Ahok kembali maju sebagai cawagub Pilkada Jakarta, PKS mendukung Anies. Sementara jejak digital fatwa tersebut masih cukup banyak dan begitu mudahnya diakses. Namun, semua ulama PKS diam seribu bahasa, tidak pernah lagi mengkaji ayat ini secara komprehensif. Mereka diam terhadap fenomena kampanye politisasi ayat dengan memonopoli tafsirnya menjadi larangan mutlak dan tunggal: larangan non Muslim menjadi gubernur.

Peristiwa ini setidaknya menunjukkan dua fenomena. Pertama, tafsir ayat itu telah dipolitisasi atau dimonopoli sesuai kepentingan partisan partai. Kedua, viralnya monopoli tafsir ayat ini dalam medsos menunjukkan bahwa mayoritas Muslim sebetulnya masih tidak banyak mengetahui ("awam”) tafsir. Sekalipun tafsir yang lengkap begitu mudahnya diakses, tinggal dua klik di google (dengan keyword Fatwa PKS tentang pemimpin non Muslim), namun semua seolah tersandera oleh monopoli tafsir di medsos.

Dengan begitu, medsos ternyata telah menjadi alat pemonopoli tafsir.

NU juga sejak 1999 telah mengeluarkan fatwa mengenai bolehnya non Muslim menjadi pemimpin. Tapi tidak sedikit sebagian kiai dan Ustad NU terlebih akar rumputnya larut dalam tafsir medsos tersebut. Maka, salah satu kesimpulannya adalah bahwa masyarakat kita berada dalam krisis pengetahuan tafsir. Tanpa pengenalan yang cukup ini, maka toleransi keagamaan dan keadaban demokrasi terancam akan terus digerogoti absolutisme dan monopoli tafsir atau islamisme.

\section{Antara Fatwa Ulama PKS dan Fatwa MUI}

Dalam fatwa Dewan Syariah Daerah PKS Surakarta 2010, secara lengkap disajikan perspektif fiqih dan tafsir soal pengangkatan pemimpin non Muslim. Dalam perspektif fiqih, dibedakan 3 
tingkatan kepemimpinan. Dua di antaranya adalah pertama, wilayah 'amah (kepemimpinan umum/mutlak) dan posisi yang memiliki nilai strategis keagamaan. Contohnya jabatan presiden, panglima perang yang terkait jihad, hakim, posisi untuk pengurusan haji dan pernikahan. Kedua, posisi kepemimpinan strategis lainnya. Contohnya posisi menteri secara umum, gubernur, kepala daerah dan sebagainya. Ulama sepakat atas pengharaman non Muslim bagi kepemimpinan mutlak dan posisi yang memiliki nilai strategis keagamaan. Sedangkan untuk jenis kepemimpinan kedua, terjadi perbedaan pendapat di antara mereka.

Fatwa ini lalu membeberkan alasan ulama yang mengharamkan maupun ulama yang membolehkan. Intinya, ulama yang mengharamkan mendasarkan pada keumuman pelarangan pemimpin non Muslim pada Al-Maidah ayat 51. Juga pada pandangan Umar bin Khattab yang berpegang pada ayat ini, yang memerintahkan dua gubernurnya, Abu Musa Al-Asyari dan Khalid bin Walid untuk memecat juru tulis dan ahli keuangannya yang non Muslim. Walau dua gubernur ini tetap pada pendirian mereka.

Alasan para ulama yang membolehkan pada dasarnya mendasarkan pada dua alasan pokok. Pertama, alasan perbedaan tingkatan kepemimpinan seperti telah disebutkan. Sehingga AlMawardi membolehkan kepemimpinan non Muslim bagi jabatan menteri pelaksana (wuzarattanfiz), bukan menteri pemegang kebijakan (wuzarat al-tafwid). Serupa dengan pandangan ini adalah pendapat Dr. Yusuf Qardhawi dan Imam Hasan Al-Banna, yang juga didasarkan pada alasan perbedaan tingkatan kepemimpinan.

Alasan kedua, alasan tafsir berdasar satu sudut pandang penafsiran atas ayat-ayat terkait pengangkatan pemimpin non Muslim. Sayyid Tanthowi misalnya dalam tafsir Al-Wasith mengatakan bahwa yang dilarang itu adalah pengangkatan pemimpin non Muslim yang mengakibatkan kerugian bagi umat Islam dan Islam, dan menghapuskan kemaslahatan Muslim. Sehingga Tanthowi membolehkan pengangkatan pemimpinan non Muslim yang tidak merugikan kaum Muslim.

Fakhrudin al-Rozi dalam kitabnya Mafatihul Ghaib berpandangan lain lagi. Ia mengatakan bahwa yang dilarang itu adalah mengangkat pemimpin non Muslim sendirian tanpa mengangkat pemimpin Muslim. Sedangkan jika mengangkat pemimpin non Muslim bersamaan dengan pemimpin Muslim maka hal ini diperbolehkan. Katanya, Mengapa tidak boleh jika yang dimaksud pelarangan dalam ayat itu, pelarangan menjadikan orang-orang kafir sebagai pemimpin, artinya adalah: mengangkat mereka tanpa mengangkat orang mukmin. Jika mengangkat non muslim dan pada saat bersamaan mengangkat orang mukmin, maka hal tersebut tidaklah dilarang.

Salah satu yang digarisbawahi oleh fatwa PKS ini adalah: “....pengharaman di atas terjadi pada wilayah-wilayah tertentu seperti Presiden, Panglima Perang, Hakim, serta Kementrian yang mengurusi masalah strategis keagamaan. Ini artinya, banyak wilayah kepemimpinan selain yang disebutkan di atas tidak bisa diberlakukan hukum ijmak di atas. Hal ini meliputi posisi menteri secara umum, gubernur, kepala daerah dan yang semacamnya."

Lalu fatwa ini sampai pada kesimpulan: "Pengangkatan non muslim dalam kepemimpinan strategis sebagaimana disebutkan dalam tingkatan kedua adalah boleh, dengan melihat secara jelas maslahat yang akan di dapat oleh kaum muslimin, serta terpenuhi syarat -syarat secara khusus. Begitu pula, kebolehan tersebut semakin terbuka jika yang diangkat bukan non muslim seorang, 
tetapi bersamanya atau didampingin dengan seorang muslim, sebagaimana disebutkan oleh imam Fakhrudin Ar-Rozi dalam tafsirnya.

Membandingkan fatwa PKS ini dengan Pendapat dan Sikap Keagamaan MUI (2016), tampak mencolok perbedaannya. Fatwa PKS dimulai dengan penukilan ayat Al-Maidah: 51, lalu mengatakan: "Ayat di atas (Al-Maidah: 51) secara dhohir berbicara tentang keumuman pelarangan mengangkat pemimpin dari golongan non muslim. Selanjutnya dalam bahasan fiqh-sebagaimana disebutkan oleh Dr. Ibrahim Abdus Shodiq dalam Fiqh Sholahiyah lil Wilayah-hal tersebut masuk dalam bab tauliyatul ahli dzimmah ( pengangkatan ahlu dzimmah / non muslim)...”

Sedangkan Pendapat dan Sikap Keagamaan MUI itu mengatakan:

1. Al-Quran surah al-Maidah ayat 51 secara eksplisit berisi larangan menjadikan Yahudi dan Nasrani sebagai pemimpin. Ayat ini menjadi salah satu dalil larangan menjadikan non Muslim sebagai pemimpin.

2. Ulama wajib menyampaikan isi surah al-Maidah ayat 51 kepada umat Islam bahwa memilih pemimpin muslim adalah wajib...."

\section{Simpulan}

Dalam fatwa PKS setebal 10 halaman itu, kalimat awal "Ayat di atas (Al-Maidah: 51) secara dhohir berbicara tentang keumuman pelarangan mengangkat pemimpin dari golongan non muslim”, dijadikan sebagai pengantar. Sehingga setelah itu dibeberkan secara lengkap dan seimbang segi-segi keumuman pelarangan dan segi-segi kekhususannya. Sedangkan dalam Pendapat dan Sikap Keagamaan MUI setebal 1 halaman itu, kalimat pada poin pertama, "Al-Quran surah al-Maidah ayat 51 secara eksplisit berisi larangan menjadikan Yahudi dan Nasrani sebagai pemimpin. Ayat ini menjadi salah satu dalil larangan menjadikan non Muslim sebagai pemimpin", dijadikan sebagai "pengantar", isi sekaligus kesimpulan hukum.

Artinya, kesimpulan hukum MUI itu sama sekali tidak merujuk pada pandangan ulamaulama fiqih dan tafsir. Hal ini diakui oleh KH. Ma'ruf Amin, bahwa pihaknya hanya membahas kata per kata yang disampaikan terdakwa, bukan tafsir atau terjemahan Surat Al-Maidah ayat 51. "Kami tidak membahas tafsir atau isinya. Kami membahas kata-katanya," ujarnya (news.detik.com).

Masalahnya, bagaimana mungkin untuk masalah sepenting itu, masalah yang bertolak dari ayat, sama sekali tidak merujuk pada pandangan ulama-ulama fiqih dan tafsir? Bagaimana mungkin menjadikan ayat sebagai dasar, namun sama sekali tidak menyinggung kandungan tafsir dan fiqihnya?

Walaupun isi fatwa MUI ini pada satu aspek tertentu berseberangan dengan fatwa Dewan Syariah PKS Surakarta, namun para ulama PKS tidak pernah mengomentari dan mempersoalkannya. Akibatnya, di tengah situasi Pilgub DKI Jakarta, kampanye dengan monopoli tafsir meruyak tanpa kendali.

Puluhan ribu buzzer dan simpatisan membanjiri medsos dengan monopoli tafsir. Pada saat bersamaan, para elit tim kampanye Ahok juga hanya menyajikan pandangan tafsir yang membolehkan pemimpin non Muslim. Argumentasi tafsirnya terpaku hanya pada sudut pandang 
ulama yang membolehkan saja. Di tengah situasi kampanye dan tajamnya polarisasi keagamaan, industri kebencian mengompori panasnya situasi.

Perlu dicatat bahwa concern tulisan ini bukan pada politik partisan, melainkan pada toleransi keagamaan (tasamuh) dan keadaban politik yang mesti dirawat bersama di tengah situasi politik apa pun.

Note: riset data dan rujukan dalam tulisan ini tidak dimungkinkan tanpa adanya kerjasama riset dan banyak diskusi dengan Rachmat Baihaky, dosen Fidikom UIN Syarif Hidayatullah Jakarta dan Ketua Pusat Layanan Kerja Sama Internasional (PLKI). Penulis mengucapkan terima kasih yang sebesar-besarnya.

\section{Daftar Pustaka}

Fealy, Greg, Bigger than Ahok: Explaining the 2 December Mass Rally, 2016

George, Cherian, Hate Spin; The Manufacture of Religious Offense and Its Threat to Democracy, diterjemahkan dan diterbitkan oleh PUSAD Paramadina, 2017.

Haadiz, Vedi dan Rakhmani, Inaya, Marketing Morality in Indonesia's Democracy, 2017

Iman, Nofie, Post-truth dan Medsos di Indonesia, Republika Online, Kamis 15 Desember 2016

Lim, Marlyna, Freedom to hate: social media, algorithmic enclaves, and the rise of tribal nationalism in Indonesia, 2017

Mietzner, Marcus dan Muhtadi, Burhanuddin, Intrepreneurs of Grievance: Drivers and Effects of Indonesia's Islamist Mobilization, 2018

Mozaffari, Mehdi, What is Islamism? History and Definition of a Concept, 2007

PPIM UIN Jakarta, Laporan Survei 2017 tentang intoleransi dan radikalisme di kalangan siswa/mahasiswa dan guru/dosen, dengan sampel sebanyak 322 orang guru/dosen dan 1859 siswa/mahasiswa.

Varagur, Krithika, Indonesia's Moderate Islam is Slowly Crumbling, 2017

https://www.alexa.com/topsites/category/World/Bahasa_Indonesia/Masyarakat/Agama/Islam

wearesocial.com

http://tools.neilpatel.com/en/analyze

https://tekno.kompas.com/read/2018/02/22/16453177/berapa-jumlah-pengguna-internet-indonesia

https://databoks.katadata.co.id/datapublish/2018/02/20/berapa-jumlah-pengguna-internet-di-indonesia beritasatu.com

http://www.muslimedianews.com/2016/04/inilah-fatwa-pks-tentang-pengangkatan.html\#ixzz5WItlKyce

https://news.detik.com/berita/3410557/ketum-mui-6-jam-bersaksi-ahok-hina-alquran-gnpf-dan-warga-marah 